\title{
THE GENUS PYLAISIADELPHA (PYLAISIADELPHACEAE, MUSCI) IN RUSSIA
} РОД РYLAISIADELPHA (PYLAISIADELPHACEAE, MUSCI) ВО ФЛОРЕ РОССИИ

\author{
Olga M. AfoninA ${ }^{1}$, Hiromi TsubOtA ${ }^{2}$ \& ElENA A. IGNATOVA ${ }^{3}$ \\ ОЛЬГА М. АФОНИНА ${ }^{1}$, ХИРОМИ ЦУБОТА ${ }^{2}$, ЕЛЕНА А. ИГНАТОВА ${ }^{3}$
}

Abstract

\begin{abstract}
The genus Pylaisiadelpha in Russia includes two species, Pylaisiadelpha tenuirostris (Bruch \& Schimp. ex Sull.) W.R.Buck and P. tristoviridis (Broth.) Afonina, Tsubota \& Ignatova, comb. nov. Descriptions, illustrations, comparisons with similar species and distribution maps in Russia are provided.
\end{abstract}

Резюме

Род Pylaisiadelpha в России включает два вида, Pylaisiadelpha tenuirostris (Bruch \& Schimp. ex Sull.) W.R.Buck и P. tristoviridis (Broth.) Afonina, Tsubota \& Ignatova, comb. nov. Даны описания, иллюстрации, сравнение с близкими видами, карты распространения видов в России.

\section{INTRODUCTION}

The genus Pylaisiadelpha was established by Cardot (1912) for two Mexican species, and for a long time was treated as an American endemic, until Buck (1984) found that species classified in Brotherella fit well the concept of this genus. Buck included all the species described in Brotherella into Pylaisiadelpha, which did not meet full acceptance, and Ando et al. (1989) and subsequent authors (e.g. Tan \& Jia Yu, 1999) demonstrated that some species of Brotherella are distinct and that the genus has to be retained. All the authors, however, agreed that Buck was correct in placing one of the most common species, Brotherella yokohamae in the genus Pylaisiadelpha.

Ando et al. (1.c.) concluded also that the North American P. tenuirostris (Bruch \& Schimp. ex Sull.) W.R.Buck and the East Asian P. yokohamae (Broth.) W.R.Buck can not be satisfactory distinguished and thus the former name should be applied to the widespread East Asian species. The idea that both species are probably closely related was pointed out already by Horikawa \& Seki (1960) and Crum (1965).
Recently, Tan \& Jia Yu (1999) found in the course of revision of the family Sematophyllaceae in China that $P$. tenuirostris and $P$. yokohamae are not totally identical and accepted both of them. The latter species however is out of scope of the present paper, because it was not found in Russia. In China $P$. yokohamae, as circumscribed by Tan \& Jia Yu (l.c.), is a more southern species, whereas $P$. tenuirostris has broader range and it is the only species of the genus present in Heilongjiang Province that is the northernmost in China, situating at the border with the Russian Far East.

From the other side, in the course of revision of the genus Stereodon for Russia, Afonina (2007) came to conclusion, that one East Asian species, Hypnum (Stereodon) tristoviride, traditionally classified within Hypnum sensu lato (cf. Ando, $1972,1995)$, can not be placed comfortably in neither Hypnum, nor Stereodon, but in some characters, especially alar cell pattern, strong margin serration, and suberect capsule is similar to Pylaisiadelpha tenuirostris. The same idea was first outlined by Ando (1956, also 1995), who however retained $H$. trisoviride in the genus Hypnum.

1 - V. L. Komarov Botanical Institute Rus. Acad. Sci., Prof. Popov Str., 2, St. Petersburg, 197376 Russia - Россия 197376, Санкт-Петербург, ул. Проф. Попова, 2, Ботанический институт им. В. Л. Комарова РАН.

2 - Miyajima Natural Botanical Garden, Graduate School of Science, Hiroshima University, Mitsumarukoyama 1156-2,Miyajima-cho, Hatsukaichi-shi, Hiroshima 739-0543, Japan

3 - Biological Faculty, Moscow State University, Moscow 119991 Russia-Россия 119991 Москва, Московский государственный университ, Биологический факультет, каф. геоботаники. 
This morphological observations fall in a very well agreement with the molecular data obtained by Tsubota et al. (2002, 2004), revealing Hypnum tristoviride unrelated to any other species of the Hypnum in the phylogenetic analysis. The genus Hypnum was found polyphyletic, but most of its species formed monophyletic groups (usually corresponding to subgeneric units of the genus), in a way similar to the result of Gardiner et al. (2005), based on other selection of taxa and different gene regions.

The analyses of Tsubota et al. $(2002,2004)$ clearly indicate the affinity of Hypnum tristoviride with Pylaisiadelpha tenuirostris. In the first analysis, the single accession of Hypnum tristoviride has been found as a sister to clade of Pylaisiadelpha tenuirostris + Wijkia hornschuchii. In the second analysis three specimens of Hypnum tristoviride were studied and they were found within a grade among three specimens of Pylaisiadelpha tenuirostris. The latter grade was a part of clade otherwise composed by species of Brotherella, Wijkia and Heterophyllium nematosum (note that Heterophyllium affine was found in another group).

An attempt to study Hypnum tristoviride with ITS was not successful, as PCR product with the standard primers, both internal and external, was not obtained (Milyutina, pers. corresp.). The same difficulty we faced with Pylaisiadelpha tenuirostris and some other Sematophyllaceae and Pylaisiadelphaceae, but never with Hypnaceae and Pylaisiaceae. This may be considered as an additional (although weak) evidence of the relationship of these taxa.

Basing on the above evidences, we transfer Hypnum tristoviride to the genus Pylaisiadelpha.

Pylaisiadelpha Cardot, Rev. Bryol. 39: 57. 1912.

Type species: $P$. rhaphidostegioides (Cardot) Cardot, $=$ P. tenuirostris (Bruch \& Schimp. ex Sull.) W.R.Buck

Plants small to medium-sized, in green, yellowish-green or brownish-golden mats. Stems creeping, brownish or dark red, rather regularly pinnately branched in one plane, teretely foliate; branches teretely to subcomplanately foliate; hyalodermis well-developed or only partial; central strand absent. Pseudoparaphyllia lanceolate, some- times slightly branched, distinctly serrate. Stem leaves erect, straight to falcate-secund, lanceolate to triangular-lanceolate, rather gradually longly and narrowly acuminate, slightly or abruptly narrowed to insertion, not plicate, concave; margins sometimes recurved below, strongly serrate above, serrulate to subentire below; costa double, short, sometimes almost lacking; laminal cells linear, with acute ends; basal cells yellow or brownish-orange with thick, subporose walls; alar cells few, in 1 row along the base, large and inflated, somewhat thickwalled, supra-alar cells distinct, quadrate. Branch leaves smaller, more strongly falcate to circinate, more strongly serrate. Autoicous or dioicous. Perichaetial leaves lanceolate, subulate, almost not plicate, serrate above. Seta yellowish-red. Capsule slightly inclined to suberect, oblong-cylindric; operculum conic and indisctincly rostrate to distinctly longirostrate; exothecial cells non-collenchimatous, exostome teeth cross-striolate below, yellowish; endostome with rather high basal membrane, with or without cilia. Spores relatively small, 12-20 $\mu \mathrm{m}$.

Familial placement of Pylaisiadelpha shifted from Entodontaceae (Cardot, 1912) to Sematophyllaceae (Brotherus, 1925; Buck, 1998), Hypnaceae (Ando et al., 1989), and finally Goffinet \& Buck (2004) classified this genus in the family Pylaisiadelphaceae.

\section{KEY FOR IDENTIFICATION OF PYLAISIADELPHA SPECIES IN RUSSIA}

1. Leaves slightly narrowed to the insertion; supra-alar cells (2-)3-7 at margin; endostome cilia rudimentary or absent; autoicous; plants usually yellow-brownish.. 1. P. tenuirostris

- Leaves rather abruptly narrowed to the insertion; supra-alar cells 1-2(-3) at margin; endostome cilia usually single, occasionally rudimentary; dioicous; plants often dark-green or yellowish-green 2. P. tristoviridis

1. Pylaisiadelpha tenuirostris (Bruch \& Schimp. ex Sull.) W.R.Buck, Yushamia 1(2): 13. 1984.- Leskea tenuirostris Bruch \& Schimp. ex Sull in Gray, Man. Bot. N.U. States 668. 1848.

Brotherella tenuirostris (Bruch \& Schimp. ex Sull.) Broth. in Engler \& Prantl, Nat. Pfl. (ed. 2) 11: 425.1925.

Figs. 1, 3 

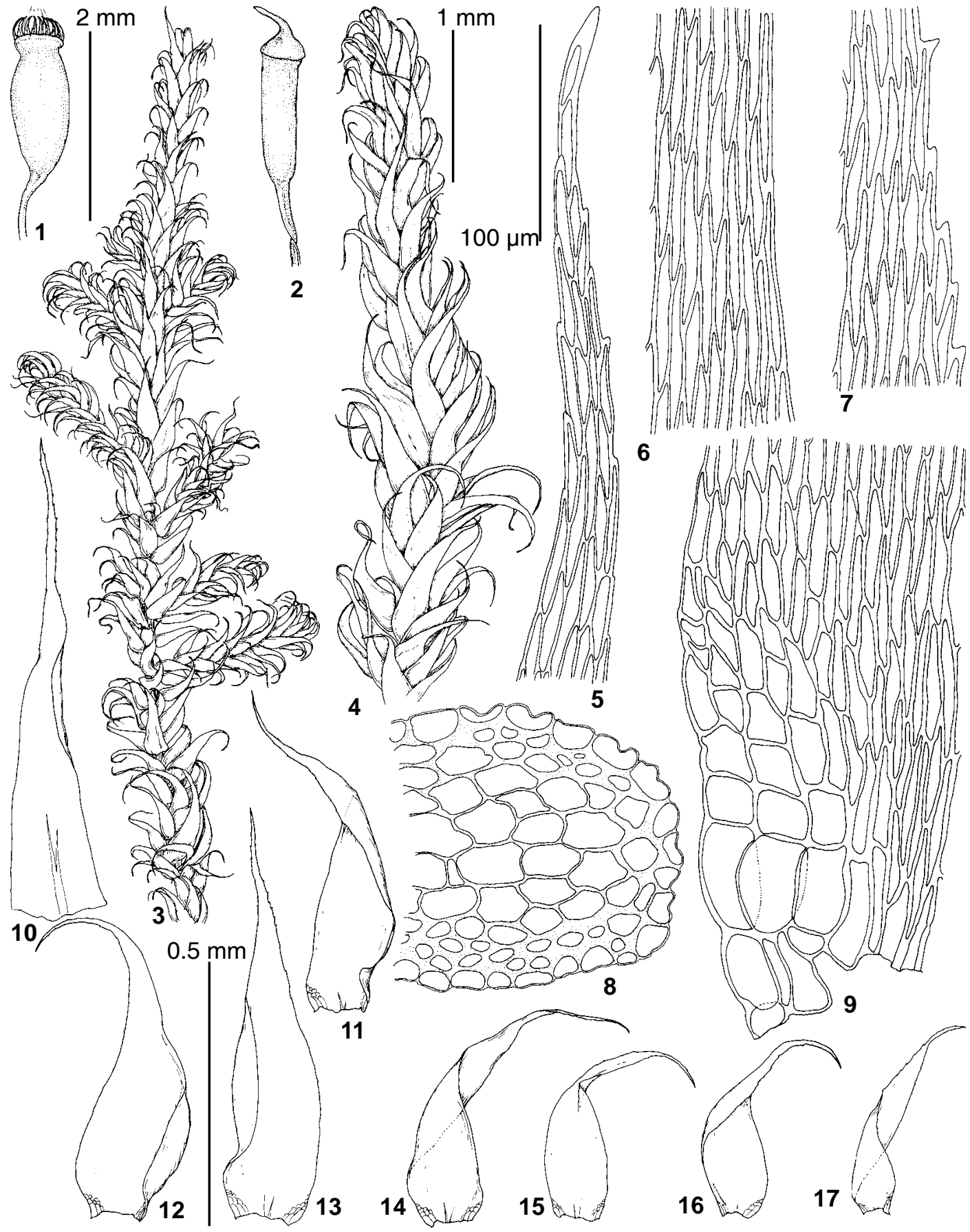

Fig. 1. Pylaisiadelpha tenuirostris (Bruch \& Schimp. ex Sull.) W.R.Buck (from from Ussurijsky Reserve, Ignatov \& Ignatova \#06-2965, MHA): 1-2 - capsules; 3-4 - habit; 5 - upper leaf cells; 6-7 - mid-leaf cells; 8 stem transverse section; 9 - basal leaf cells; 10 - perichaetial leaf; 11-13 - stem leaves; 14-17 - branch leaves. Scale bars: $2 \mathrm{~mm}$ for $1-3 ; 1 \mathrm{~mm}$ for $4 ; 0.5 \mathrm{~mm}$ for $10-17 ; 100 \mu \mathrm{m}$ for $5-9$.

Plants small, in soft, green, or more commonly yellow to brownish, slightly glossy mats. Stems 0.5-1.0 cm long, subpinnately branching; branches to $5 \mathrm{~mm}$ long, slightly complanately foliated. Stem leaves $0.7-1.3 \times 0.20-0.35 \mathrm{~mm}$, erect and falcatesecund, concave, oblong-lanceolate, gradually 


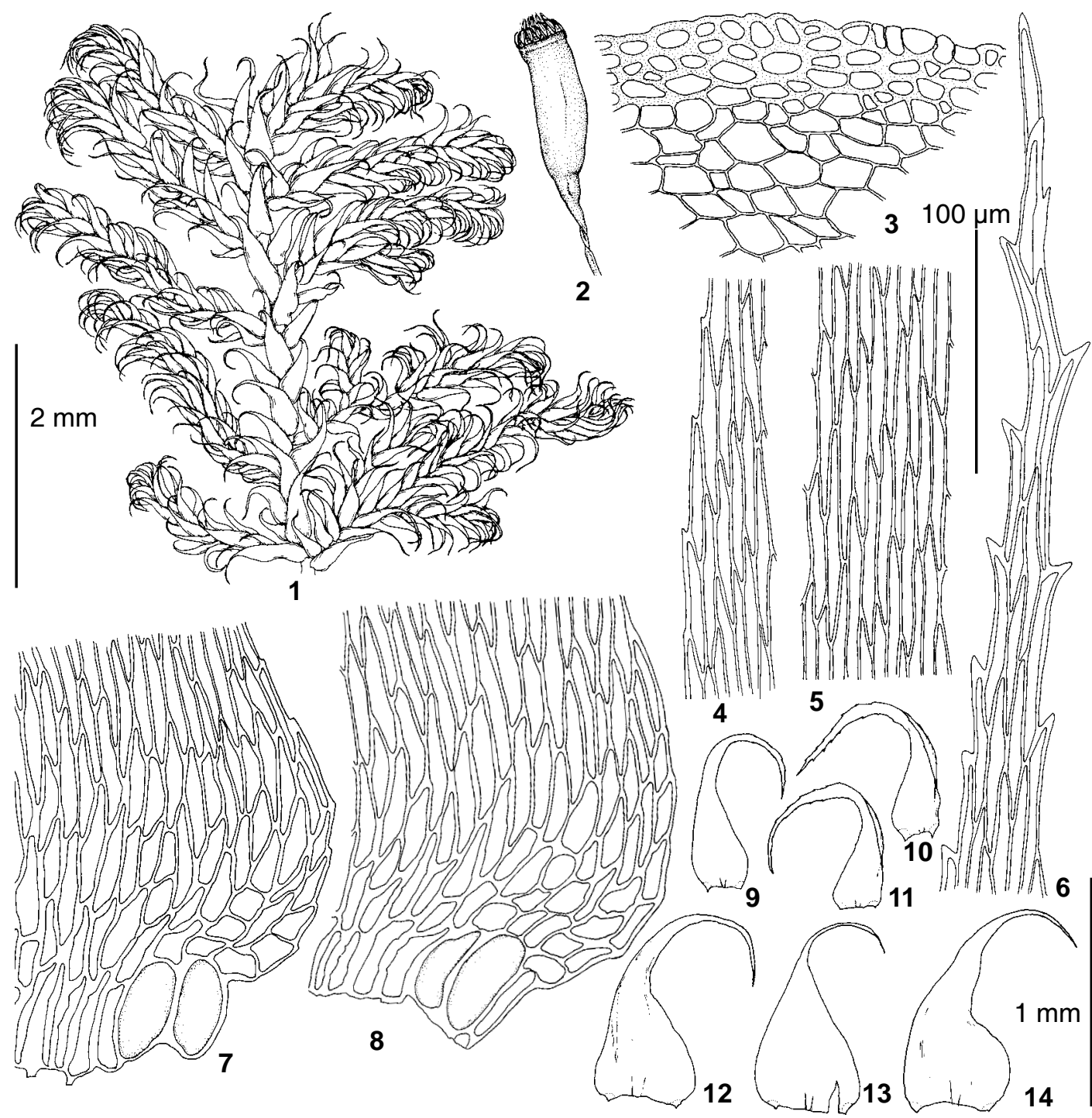

Fig. 2. Pylaisiadelpha tristoviridis (Cardot) Afonina, Tsubota \& Ignatova (from Vladivostok, Ignatov \& al. \#06-2017, MHA): 1 - habit; 2 - capsule; 3 - stem transverse section; 4-5 - mid-leaf cells; 6 - upper leaf cells; 7-8 basal leaf cells; 9-11 - branch leaves; 12-14 - stem leaves. Scale bars: $2 \mathrm{~mm}$ for 1-2; $1 \mathrm{~mm}$ for 9-14; $100 \mu \mathrm{m}$ for 3-8.

long-acuminate, yellowish at base, margins \pm reflexed below, serrate above; median laminal cells linear, 50-80 x 4-6 $\mu \mathrm{m}$, upper laminal cells shorter, 35-40 × $5 \mu \mathrm{m}$; alar group triangular, alar cells oblong, moderately inflated, yellowish, with rather thick walls, in 1(-2) rows, supra-alar cells 3-7 along leaf margin, subquadrate to short rectangular, thick-walled. Branch leaves similar to stem leaves but smaller. Autoicous. Seta smooth, brown, 10-15 mm. Capsule erect and symmetric, 1.5-2.0 mm long, cylindric or oblong-cylindric, yellowish-brown. Operculum obliquely long-ros- trate, to $0.8 \mathrm{~mm}$. Exostome teeth ca. $300 \mu \mathrm{m}$ long; endostome rudimentary; basal membrane ca. 80 $\mu \mathrm{m}$ high; cilia none. Spores 12-20 $\mu \mathrm{m}$. Filamentose multicellular propagulae are characteristic for some populations of this species, but they were never found in material from Russia.

SPECIMENS EXAMINED: Amurskaya Province: Zeya Distr., Zeya State Reserve, Teplyj Creek, 7.VIII.1980 L.I. Abramova \#5 (MW); same, 21.IX.1979 Petelin s.n. (MW); same, Gilyuj River, 11.VIII.1980 L.I. Abramova \#81 (MW). Khabarovsk Territory: Verkhne-Bureinsky Distr., $5 \mathrm{~km}$ to ESE from Tyrma 


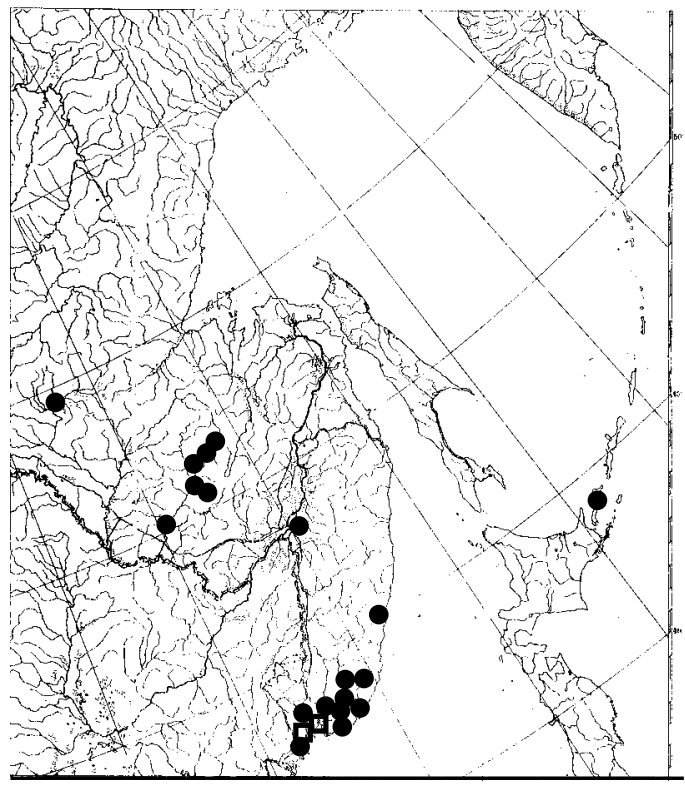

settlement, 20.IX.1940 Mesherov s.n. (LE); Khekhtsirskij Reserve, 1.IX.1979 Bondartseva s.n. (LE). Primorsky Territory: Khasan Distr., "Kedrovaya Pad" Reserve, 9.X.1954 Vasil'eva s.n. (LE); Sikhote Alin Reserve, vicinity of Sibichi settlement, 7.IX.1946 M.V. Korchagina \& A.A. Korchagin s.n. (LE); Slavyansk Distr., Suputinsky Reserve, IX.1961 Vasil'eva s.n.(LE); Ussurijsky Reserve, Ignatov \& Ignatova \#06-3456 (MHA); Lozovski Reserve, 20.IX.1978, Bardunov \& al. s.n. (LE); Shkotovo Distr:: upper Usmuha River, 20.IX.1946 Kolesnikov s.n. (LE); Litovka (Khualaza) Mt., 15.IX.1995 Konovalova \& al s.n. (MHA); Pidan (Livadiyskaya) Mt., Ignatov \& Ignatova \#06-2146 (MHA); Vicinity of Vladivostok, 27.VIII.1963 Selivanova-Gorodkova s.n. (LE); Vladivostok Area, Okeansky Ridge, near Shamarsky Pass, Ignatov \& al. \#06-2024, 06-2006, 06-2010 (MHA); Partizanskij Distr., Olkhovaya Peak, Ignatov \& al. \#06-2845, 06-2308 (MHA). Sakhalinskaya Province: Kuril Islands, Kunashir Island, Ozernaya Creek, Ignatov \#06-1449 (MHA).

Distribution. Japan (Honshu, Shikoku, Kyushyu), Eastern North America and Central America (Mexico, Guatemala, Panama). Russia: Primorsky and Khabarovsk Territories, Amurskaya and Sakhalinskaya Provinces. It grows in forest mostly on trunk bases, rotten wood, rarely on stones and rocks.

Plants reported from South Siberia, Baikal region (Bardunov, 1969, Kazanovsky, 1991) do not belong to the genus Pylaisiadelpha and will be discussed elsewhere.

Differentiation. Pylaisiadelpha tenuirostris shows some superficial resemblance with slen-
Fig. 3. Distribution of Pylaisiadelpha tenuirostris (solid circles) and P. tristoviridis (open squares) in Russia.

der species of Stereodon, such as S. pallescens (Hedw.) Mitt., but it is distinguished by erect capsules and inflated alar cells.

2. Pylaisiadelpha tristoviridis (Broth.) Afonina, Tsubota \& Ignatova, comb. nov. - Stereodon tristoviridis Broth., Hedwigia 38: 234. 1899. Hypnum tristoviride (Broth.) Paris, Ind. Bryol. Suppl. 1: 214. 1900.

Figs. 2, 3

Plants rather slender, in yellowish-green or brownish-green mats. Stems 5-10 cm long, regularly and densely pinnately branching; branches 5-10 mm long, slightly complanately foliate. Stem leaves $0.8-1.5 \times 0.3-0.5 \mathrm{~mm}$, falcate-secund, triangular-lanceolate, rather abruptly narrowed to the insertion, gradually longly and narrowly acuminate; median leaf cells (50-)70-90 x 4-6 $\mu \mathrm{m}$. Branch leaves 0.7-1.2 x 0.20-0.35 mm. Dioicous. Seta yellowish-red, to $3.2 \mathrm{~cm}$. Capsule inclined to suberect, 1.2-1.5 mm long, oblong-cylindric. Operculum short-rostrate. Exostome teeth ca. $0.40-0.43 \mathrm{~mm}$ long. Basal membrane ca. $0.13 \mathrm{~mm}$ high; cilia 1-2, as long as the segments. Spores 14-20 $\mu \mathrm{m}$.

SPECIMENS EXAMINED: Primorsky Territory: Khasan Distr., "Kedrovaya Pad" Reserve, 16.X.1974 Bardunov s.n. (IRK, LE); Vladivostok Area, Okeansky Ridge, near Shamarsky Pass, Ignatov \& al. \#06-2017 (MHA).

Distribution. Japan (Hokkaido, Honshu, Shikoku, Kyushyu), Korea, Taiwan, China. In Russia this species was collected few times in Primorsky Territory. It grows in forest on rotten logs.

Differentiation. Pylaisiadelpha tristoviridis shows some superficial resemblance with Stereodon fauriei and $S$. densirameus, but it is distinguished from both these species by large, inflated, somewhat thick-walled, "bubble-like"-shaped alar cells vs. smaller, thin-walled, isodiametric or ovate alar cells, central strand absent vs. present, sexual condition dioicous vs. autoicous.

Alar group indicates the affinity with Pylaisiadelpha tenuirostris, but superficially these species are rather distinct by characters mentioned in the key.

\section{ACKNOWLEDGEMENTS}

The work was partly supported by RFBR grants 05-04-48705 and 07-04-00013, and HШ7063.2007.4. 


\section{LITERATURE CITED}

[AFONINA, O.M.] АФОНИНА, О.М. 2007. Stereodon. Флора мхов России. [Moss Flora of Russia], http:// arctoa.ru/Flora/taxonomy-ru/Stereodon1.htm

ANDO, H. 1956. The Hypnum species restricted to Japan and adjacent areas (1). - J. Sci. Hiroshima Univ., Ser. B, Div. 2, Bot. 7: 143-152.

ANDO, H. 1972. Studies on the genus Hypnum Hedw. (I). J. Sci. Hiroshima Univ., Ser. B, Div. 2, Bot. 14: 53-73.

ANDO, H. 1995. The genus Hypnum (Musci) in Japan.II. Nat. Envir. Sci. Res. 8: 67-99.

ANDO, H., T. SEKI \& W.B.SCHOFIELD 1989. Generic distinctness of Brotherella from Pylaisiadelpha (Musci). Bryologist 92(2): 209-215.

[BARDUNOV, L.V.] БАРДУНОВ Л.В. 1969. Определитель листостебельных мхов Центральной Сибири. - [Handbook of mosses of the Central Siberia] Л., Наука [Leningrad, Nauka], 329 pp.

BROTHERUS, V.F. 1925. Musci. — In: Engler, A. \& K. Prantl (eds.), Die Naturlichen Pflanzenfamilien, ed. 2, 11: 1-522. W. Engelmann, Leipzig.

BUCK, W.R. 1984. Pylaisiadelpha replaces Brotherella (Sematophyllaceae). - Yushania 1(2): 11-13.

BUCK, W.R. 1998. Pleurocarpous mosses of the West Indies. - Mem. New York Bot. Garden 82: 1-400.

CARDOT, I. 1912. Pylaisiadelpha Card., genre nouveau de la famille des Entodontacees. - Rev. Bryol. 39: 57-58.

CRUM, H.A. 1965. Brotherella tenuirostris in Canada. - Bryologist 88: 27-28.
GARDINER, A.A., M. S. IGNATOV, S. HUTTUNEN \& A.V. TROITSKY 2005. On resurrection of the families Pseudoleskeaceae Schimp. and Pylaisiaceae Schimp. (Musci, Hypnales). - Taxon 45: 651-663.

GOFFINET, B. \& W.R. BUCK 2004. Systematics of the Bryophyta (mosses): from molecules to a revised classification. - Monographs in Systematic Botany from the Missouri Botanical Garden 98: 205-239.

HORIKAWA, Y. \& T. SEKI 1960. Studies on the genus Brotherella in Japan (1). - Hikobia 2: 75-98.

[KAZANOVSKY, S.G.] КАЗАНОВСКИЙ С.Г. 1991. К бриофлоре Байкальского заповедника. - [On the bryoflora of Baikal Reserve]. Бриология в СССР, ее достижения и перспективы (Мат. конф., Львов, 10-12 сент. 1991) (ред. Демкив, О. Т.), Львов, АН СССР, АН УССР [In: Demkiv, O. T. (ed.), Briologia v SSSR, ee dostizheniya i perspektivy (Proc. Conf., Lvov, 10-12 Sept. 1991). Lvov, Akad. Nauk SSSR \& Akad. Nauk Ukr. SSR]: 94-98.

TAN, B.C. \& JIA YU 1999. A preliminary revision of Chinese Sematophyllaceae. - J. Hattori Bot. Lab. 86: 1-70.

TSUBOTA, H., T. ARIKAWA, H. AKIYAMA, E. DE LUNA, D. GONZALES, M. HIGUCHI \& H. DEGUCHI 2002. Molecular phylogeny of hypnobryalean mosses as inferred from the large scale dataset of chloroplast rbcL, with special reference on the Hypnaceae and possibly related families. - Hikobia 13: 645-665.

TSUBOTA, H., E. DE LUNA, D. GONZALEZ, M.S. IGNATOV \& H. DEGUCHI 2004. Molecular phylogenetics and ordinal relationships based on analyses of a large-scale data set of $600 \mathrm{rbcL}$ sequences of mosses. - Hikobia 14: 149-170. 